\title{
Ordovician conodonts from the Bulltinden Formation, Motalafjella, central-western Spitsbergen
}

\author{
HOWARD A. ARMSTRONG, HANS A. NAKREM AND YOSHIHIDE OHTA
}

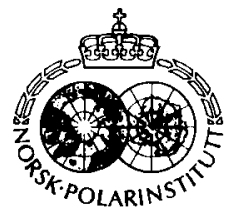

Armstrong, H. A., Nakrem, H. A. \& Ohta, Y. 1986: Ordovician conodonts from the Bulltinden Formation, Motalafjella, central-western Spitsbergen. Polar Research 4 n.s., 17-23.

\begin{abstract}
Seven samples from the Limestone and Boulder Conglomerate Members of the Bulltinden Formation have yiclded poorly preserved conodonts. On tentative identifications Periodon aculeatus Hadding and Prioniodus cf. $P$. alobatus Bergström at the base of the formation suggest an Ordovician lower Caradoc, or older agc. This confirms that the Vestgötabrecn Formation unconformably beneath underwent highpressure metamorphism during the Taconic and/or Finmarkian phases of the Caledonian orogeny. The conodonts show affinity to the North Atlantic Province suggesting a deeper water marine depositional cnvironment. Conodont colour alteration indices of five indicate that the Bulltinden Formation was heated to temperatures in excess of $300^{\circ} \mathrm{C}$, probably during the middle-upper Silurian main Caledonian uplift cvent.
\end{abstract}

Howard A. Armstrong. University of Newcastle upon Tyne, Newcastle, England: Hans A. Nakrem, Paleontologisk Museum, University of Oslo, Sarsgt. I, Oslo 3, Norway; Yoshihide Ohta, Norwegian Polar Research Institute, Rolfstangveien 12, 1330 Oslo Lufthavn; April 1985 (revised November 1985).

Thick Precambrian and Lower Palaeozoic sediments in central western Spitsbergen are highly deformed and have been classified into five formations (Figs. 1 and $2 \mathrm{a}$ ). The uppermost of these formations is the Bulltinden Formation of Lower Palaeozoic age (Harland et al. 1979; Hjelle et al. 1979; Figs. 2a and 2b). The Bulltinden Formation in Motalafjella is exposed in the centre of an overturned syncline, the axial plane of which dips moderately to the west (Fig. 2c). This formation lies structurally beneath, but stratigraphically and uncomformably above the Vestgötabreen Formation, a high-pressure metamorphic complex (Horsfield 1972; Ohta 1979; Ohta et al. 1984; Ohta et al. 1986; Fig. 2c).

The Bulltinden Formation comprises three members, at the base the Limestone Member, the Boulder Conglomerate Member, and at the top the Sandstone-Shale Member. The Sandstone-Shale Member occurs outside Fig. 2b, the area under consideration. Only the lower two members have yielded conodonts and are described in ascending order (Table 1).

\section{Limestone Member (Fig. 2b)}

This member is typically $30-80 \mathrm{~m}$ thick and consists of sheared, dark limestones. At the base an unconformity is marked by the presence of a

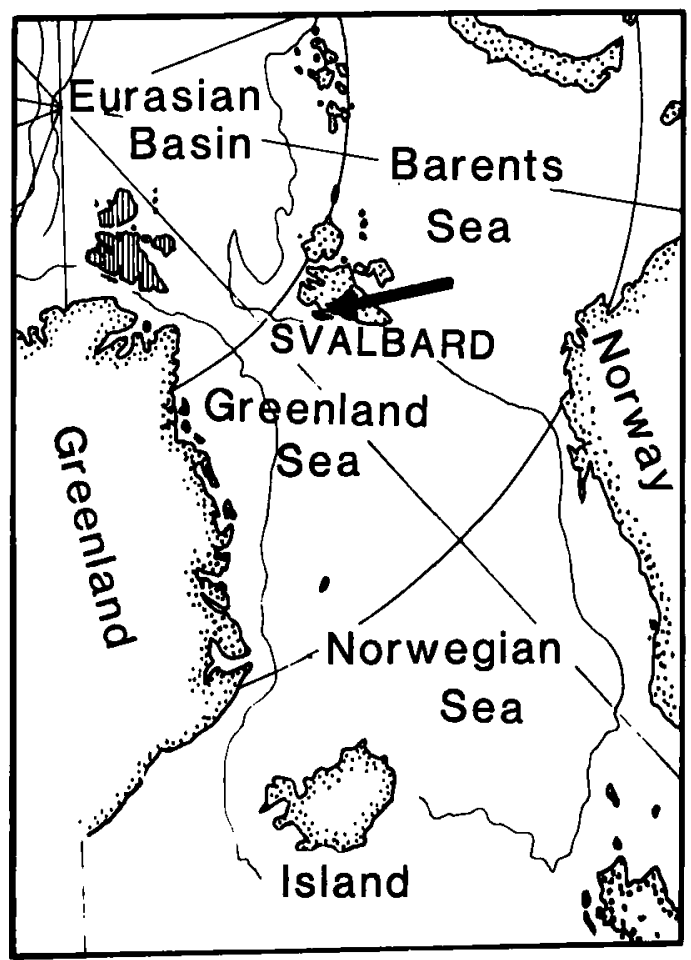

Fig. 1. Svalbard, with its pre-Tertiary position in the northeast of Greenland (shadowed). Arrow = Motalafjella. 

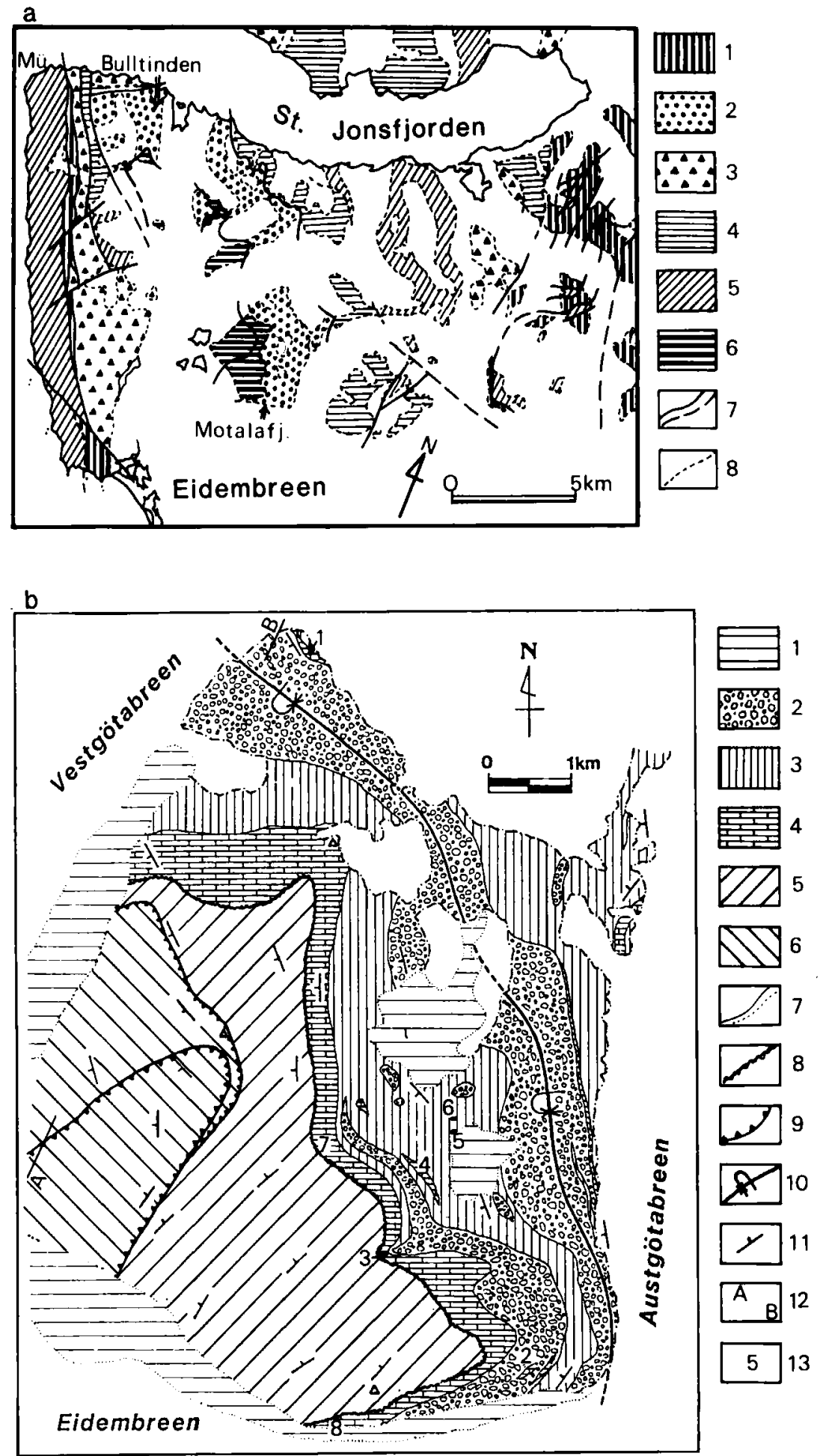


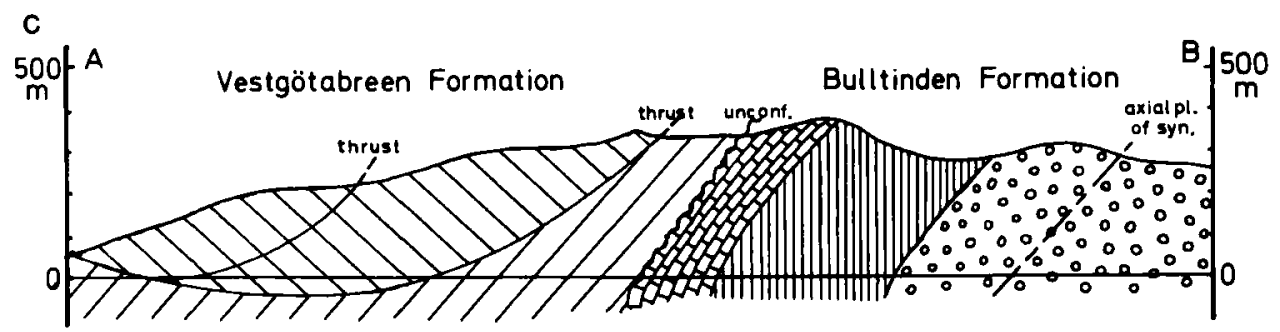

Fig. 2. Motalafjella. a. Geological map of southern side of St. Jonsfjorden, central-western Spitsbergen. - Legend: 1. Carboniferous and Permian; 2. Bulltinden Formation; 3. Eocambrian tillite formation; 4. Calc-argillo-volcanic formation; 5. Quartzite-shale formation; 6. Vestgötabreen Formation; 7. Fault and thrust; 8. Lithological boundary. Mü: Müllerneset. - b. Geological map of Motalafjella. - Legend: 1. Moraine; 2, 3, 4. Bulltinden Formation: 2. conglomerate of the Boulder Conglomerate Member, 3. sandstone and shale of the Boulder Conglomerate Member, 4. Limestone Member; 5, 6. Vestgötabreen Formation: 5. Lower Unit (low grade), 6. Upper Unit (high grade); 7. Lithological boundaries; 8. Unconformity; 9. Thrust; 10. Axial trace of overturned syncline; 11. Bedding and cleavage; 12. Position of geological profile; 13. Fossil localities. 1 and 2 were reported by Scrutton et al. (1976). - c. Geological profile along the western part of Motalafjella.

fossiliferous, sandy, grey limestone-conglomerate containing large angular to rounded clasts of garnet-mica schists, metabasites, greenschists and dolomites. These lithologies are found within the Vestgötabreen Formation (Ohta et al. 1984). Conodont samples 83 JP 159, loc. 3; 83 JP 167, loc. 4; 83 JP 171, loc. 7; and 83 JP 190, loc. 8 (all localities are shown in Fig. 2b) were collected through this member.

Sample 83 JP 159 (loc. 3, Fig. 2b) collected for conodonts also contained gastropods including Maclurites which most probably indicate a middle to late Ordovician age (J. S. Peel, pers. comm.).

Table 1. Specimen abundances and processed sample weights. F denotes fragments only.

\begin{tabular}{|c|c|c|c|c|c|c|c|}
\hline Sample nos. & $\begin{array}{l}\stackrel{a}{2} \\
\stackrel{2}{2} \\
\infty\end{array}$ & $\begin{array}{l}\hat{0} \\
\stackrel{1}{2} \\
\infty \\
\infty\end{array}$ & $\begin{array}{l}\vec{E} \\
\stackrel{\Xi}{S} \\
\infty\end{array}$ & $\begin{array}{l}\stackrel{g}{9} \\
\stackrel{2}{=} \\
\infty\end{array}$ & $\begin{array}{l}\stackrel{0}{0} \\
\stackrel{0}{\infty} \\
\infty\end{array}$ & $\frac{8}{\stackrel{0}{a}}$ & $\begin{array}{l}\text { D } \\
\text { ñ } \\
2 \\
2 \\
n\end{array}$ \\
\hline Weight processed (kg.) & 2.9 & 6.2 & 0.5 & 0.4 & 0.9 & 1.2 & 1.4 \\
\hline ?Belodina sp. indet. & & 1 & & & & & \\
\hline ?Dapsilodus sp. indet. & & 1 & & & & & \\
\hline Panderodus sp. & 1 & 1 & $\mathrm{~F}$ & & $\mathbf{F}$ & $\mathrm{F}$ & \\
\hline Periodon aculeatus & & & & & & & \\
\hline M & 1 & 2 & & & & & \\
\hline $\mathrm{Sb}$ & & 2 & & & & & \\
\hline Prioniodus cf. P. abbatus & & & & & & & \\
\hline Sa & & 1 & & & & & \\
\hline 'prioniodiform' & & 1 & & & & & \\
\hline $\begin{array}{l}\text { Protopanderodus sp. indet. } \\
\text { asymmetrical acodontiform }\end{array}$ & 1 & & & & & & \\
\hline $\begin{array}{l}\text { ?Scalpellodus sp. indet. } \\
\text { symmetrical P }\end{array}$ & & 1 & & & & & \\
\hline $\begin{array}{l}\text { Walliserodus } \mathrm{cf} W \text {. curvatus } \\
\text { symmetrical } \mathrm{P}\end{array}$ & & & & & & & 1 \\
\hline $\begin{array}{l}\text { Walliserodus sp. indet. } \\
\text { symmetrical } \mathrm{P}\end{array}$ & & 1 & & & & & \\
\hline $\begin{array}{l}\text { ?Plectodina sp./?Oulodus sp. } \\
\text { S element }\end{array}$ & & & & & & & 1 \\
\hline $\begin{array}{l}\text { Oistodiform element sp. indet. } \\
\text { Genus and } \mathrm{sp} \text {. indet. }\end{array}$ & 1 & & & & & 1 & \\
\hline
\end{tabular}


20 H. A. Armstrong, H. A. Nakrem \& Y. Ohta
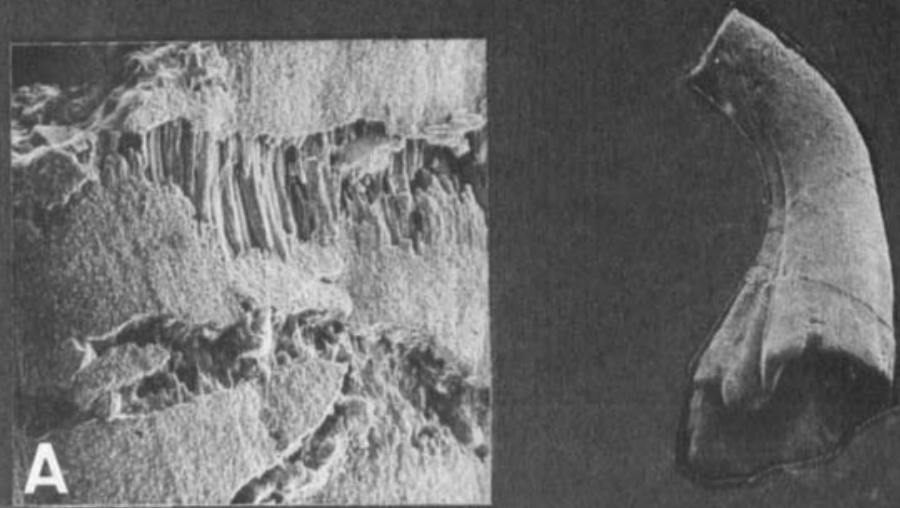

B
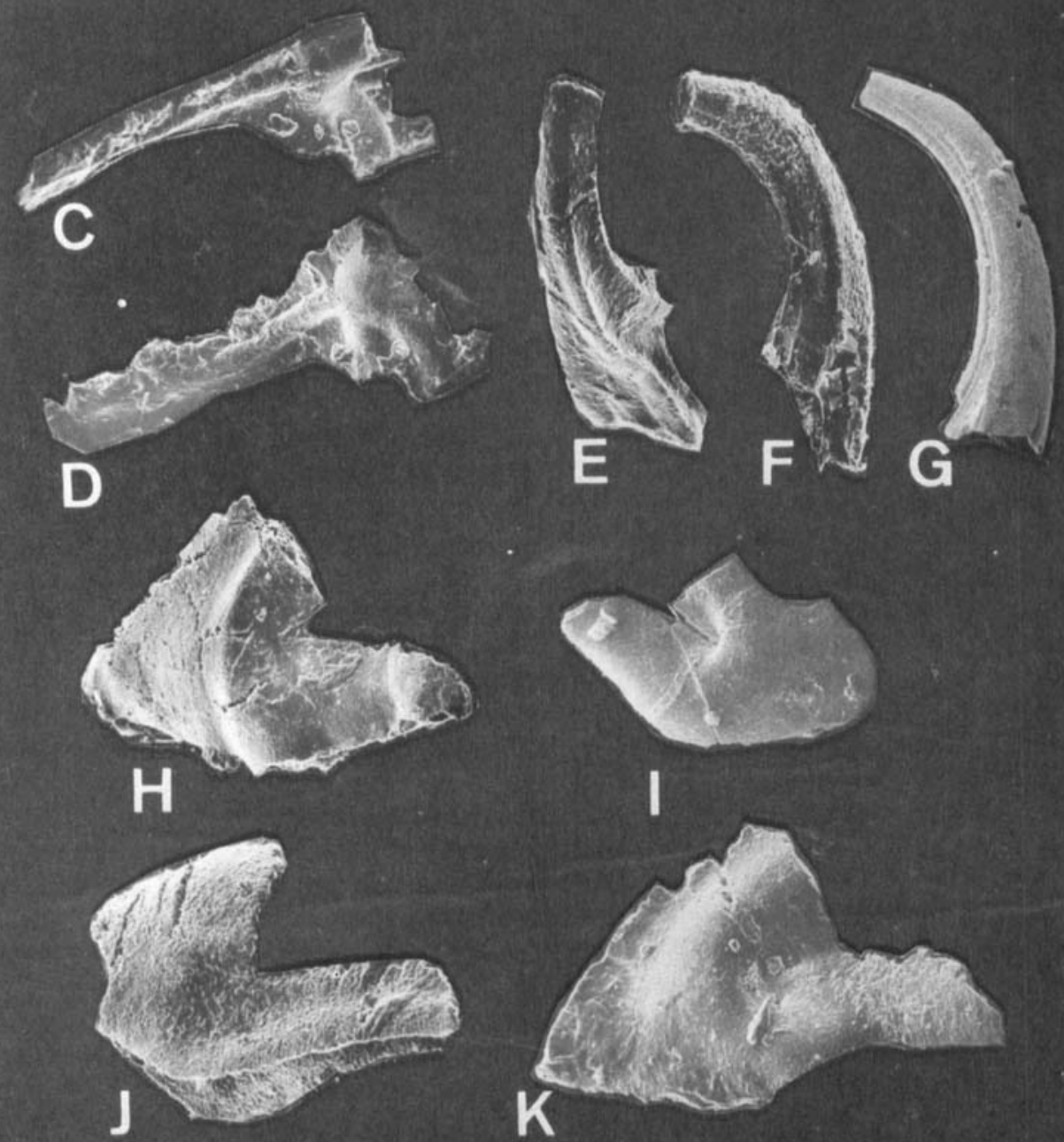


\section{Boulder Conglomerate Member (Fig. 2b)}

The Boulder Conglomerate Member is between $30 \mathrm{~m}$ and $250 \mathrm{~m}$ thick, and comprises conglomerates and sandstone-shale alternations; the latter predominate in the upper part of the Member, and laterally both show rapid thickness variation. The conglomerate comprises clasts of crystalline limestone, dolomite, quartzites, serpentinite, greenschists and mica schists. These are interspersed with slumped limestone lenses containing olistostromes up to $20 \mathrm{~m}$ across, and isolated pebbles and thin lenses of conglomerate. In Motalafjella the Conglomerate Member contains several fossiliferous lenses of limestone which have yielded a lower Silurian fauna of Paleofavosites, Catenipora, Tryplasma, Ketophyllum and Harpidium (aff. Lissocoelina) at loc. 1 (Fig. 2b) (Scrutton et al. 1976). Ohta et al. (1984) also recorded additional fossiliferous localities within the member, finding gastropods. corals cephalopods and trilobites. In a petrographic study of the Bulltinden Formation, Horsfield (1972) assumed an age of Ordovician or younger.

Conodont samples collected from the limestone lenses in the Boulder Conglomerate Member include $83 \mathrm{JP} 168$, loc. 5; $83 \mathrm{JP} 169$, loc. 6; and 75 YO 536, loc. 1 (all localities in Fig. 2b) (the last from the upper part of the Member and is the same as locality 3 in Fig. 1 of Scrutton et al. 1976).

\section{The conodont faunule}

Four dark, coarse-grained limestone samples were collected from the Limestone Member and three from the Boulder Conglomerate Member (Fig. 2b). These underwent standard processing techniques for conodonts. Conodonts were moderately abundant only in sample $83 \mathrm{JP} 167$ (loc. 4 , Fig. 2b) and preservation was poor in all cases. Specimens record a conodont colour alteration index (C.A.I.) of five, which suggests heating to at least $300^{\circ} \mathrm{C}$ (Epstein et al. 1977). Many specimens are fragmentary or fractured and exhibit recrystallization (Fig. 3A).

It is not the aim of this paper to present a taxonomic study of the conodonts, merely to record their presence and provide dates for the Bulltinden Formation. Unfortunately the specimens of Belodina sp. ?Plectodina sp./?Oulodus sp., the Sa element of Prioniodus cf. $P$. alobatus and four specimens of Periodon aculeatus ( $\mathrm{M}$ and $\mathrm{Sb}$ elements) were lost in the SEM vacuum. The latter species are critical for dating the base of the Limestone Member and the Material is to be recollected for a larger taxonomic study.

The conodont faunule is of low diversity and abundance (Table 1). Samples 83 JP 159 (loc. 3, Fig. 2b) at the base of the Limestone Member and $83 \mathrm{JP} 167$ (loc. 4, Fig. 2b) in the upper part of the Limestone Member contain Periodon aculeatus Hadding, a species known to range from the late Arenig Microzarkodina ozarkodella subzone to the Llandeilian Pygodus anserinus Biozone (Ziegler 1981), and may range into the lowest Caradoc (Repetski \& Ethington 1977). A fragmented specimen of the oistodiform $M$ element of $P$. aculeatus in $83 \mathrm{JP} 159$ lacks discernible denticles on the anterior edge of the cusp; this may be an artifact of preservation or suggestive of specimens closer to $P$. flabellum (Lindström 1955; Løfgren 1978). If the latter is the case, the lower part of the Limestone Member may be restricted to the Arenig (Ziegler 1981). Sample 83 JP 167 contains two elements tentatively assigned to Prioniodus cf. $P$. alobatus as the amorphognathiform element is absent and the prioniodiform element lacks a complete posterior process. Confirmation of the presence of $P$. alobatus would suggest a lower Caradoc age (Bergström 1971; Ziegler 1981) for the upper part of the Limestone Member. The remaining samples from the lower and middle parts of the member yield undiagnostic conodonts of Lower-Middle Ordovician aspect.

Sample 75 YO 536 (loc. 1, Fig. 2b) from near the top of the Boulder Conglomerate Member, contains a broken ramiform element which may be assigned to ?Plectodina sp. or ?Oulodus sp.

Fig. 3. Conodonts. A: Partial recrystallization developed in a Panderodus sp. A 40849/11, $\times 165$. B: Panderodus sp. A 40851/13, $\times$ 5). C. D: Prioniodus of. alobatus, prioniodiform element, inner side (C), outer side (D). A 40848/2, $\times 77$. E: Juanognathus sp. A $40848 / 17.88 \times$. F, G: Panderodus cf. ?gracilis, A $40848 / 19$ (F), A 40851 (G), $\times 88$. H, J, K: ?Periodon sp. indet, M element. A $40848 / 10, / 11, / 9, \times 88$ I: Gen. \& sp. indet. A 40850/11, $\times 82$.

The conodont collection is housed at the Paleontologisk Museum, University of Oslo, under the numbers A $40486-40851.83 \mathrm{Jp}$ $159=$ A 40846; $83 \mathrm{JP} 190=$ A 40847; $83 \mathrm{JP} 167=$ A 40848; $83 \mathrm{JP} 168=$ A 40849; $83 \mathrm{JP} 169=\mathrm{A} 40850,83 \mathrm{JP} 171$ and $75 \mathrm{YO}$ $536=$ A 40851 . 
This would suggest late Ordovician or early Silurian age.

The faunule recovered from Motalafjella shows an affinity with the North Atlantic Province (Barnes et al. 1973) and facilitates correlation in terms of the Balto-Scandinavian conodont zonal succession (Bergström 1971). Faunas representative of the North Atlantic Province apparently reflect 'normal' marine conditions at either high or low latitudes (Barnes \& Fåhraeus 1975). The Periodon-Prioniodus association is found in the deeper water environments of the shelf margin or continental slope (Barnes et al. 1973; Barnes \& Fåhraeus 1975; Ethington \& Repetski 1984).

\section{Discussion}

Conodont and macrofossil dates suggest that the Limestone Member of the Bulltinden Formation is of probable lower Caradoc or older age, while the upper part of the Boulder Conglomerate Member may range into the lower Silurian. These dates place a minimum age on the deformation and high-pressure metamorphism of the Vestgötabreen Formation which is unconformably overlain by the Bulltinden Formation. These events are now known to be older than previously supposed. i.e. Scrutton et al. (1976) inferred the events were older than lower Silurian, but provided no specific date. We suggest they can be correlated with the early Caledonian, Taconic and/or Finmarkian phases of orogeny.

In northern Svalbard gneisses and migmatites associated with the main Caledonian uplift have yielded K-Ar dates of $360-430 \mathrm{Ma}$ (Gayer et al. 1966: Ohta et al. 1986). These postdate the Bulltinden Formation.

All conodont specimens record a C.A.I. value of five (Epstein et al. 1977), suggesting that the Bulltinden Formation has been metamorphosed by temperatures in excess of $300^{\circ} \mathrm{C}$. This is in general agreement with chemical data presented by Ague \& Morris (1985) which suggest that garnet-mica schists at Müllerneset (Fig. 2b), $10 \mathrm{~km}$ to the northwest of the present area, were formed at $460-517^{\circ} \mathrm{C}$. Both sets of data suggest a post-Bulltinden Formation metamorphism event which would appear to correlate with the middle upper Silurian, main Caledonian uplift event, the Scandian phase. This thermal event is probably simultaneous with the formation of the overturned syncline in Motalafjella (Fig. 2c).
Thus, the Bulltinden Formation separates two deformation and metamorphic phases in the Caledonian orogeny in Svalbard, the older Taconic/ Finmarkian phase with a high-pressure metamorphism and the younger Acadian/Scandian phase with an intermediate $\mathrm{P} / \mathrm{T}$ metamorphism. The younger event has been observed in wide areas of the Svalbard Caledonides, while the Taconic Formation one is restricted to occur in some small tectono-stratigraphic units in western Spitsbergen.

Acknowledgements. - We are grateful to Dr. David Bruton. Paleontologisk Museum, University of Oslo, Dr. John S. Pecl, Geological Survey of Greenland, Copenhagen, and Dr. M. P. Smith. University of Nottingham for encouragement and advice.

\section{References}

Aguc. J. J. \& Morris A. P. 1985: Metamorphism of the Müllerneset Formation, St. Jonsfjoden, Svalbard. Polar Research 3. n.s. 93-106.

Barnes. C. R. \& Făhracus. L. E. 1975: Provinces, communitics and the proposed nektobenthic habit of Ordovician conodontophorids. Lethaia 8, 133-149.

Barnes. C. R., Rexroad. C. B. \& Miller. J. F. 1973: Lower Palaeozoic conodont provincialism. In F. H. T. Rhodes (cd.): Conodont palcozoology. Geological Society of America Special Paper 141, 157-190.

Bergström. S. M. 1971: Conodont biostratigraphy of the Middle and Upper Ordovician of Europe and eastern North America. Geological Society of America, Memoir 127. 83-162.

Epstein. A. G., Epstein, J. B. \& Harris, L. D. 1977: Conodont colour alteration-an index to organic metamorphism. U.S. Geological Survey Professional Paper 995, 1-27.

Ethington. R. L. \& Repetski. J. E. 1984: Palacogeographic distribution of Early Ordovician conodonts in central and western United States. Geol. Soc. Am. Spec. Paper 196, 89102.

Gayer, R. A., Gee, D. G., Harland, W. B., Miller, J. A., Spall, H. R., Wallis, R. H. \& Winsnes, T. S. 1966: Radiometric age determinations on rocks from Spitsbergen. Nor. Polarinst. Skr. 137, 1-39.

Harland, W. B., Horsfield, W. T., Manby, G. M. \& Morris, A. P. 1979: An outline pre-Carboniferous stratigraphy of central western Spitsbergen. Nor. Polarinst. Skr. 167, 119144.

Hjelle, A., Ohta, Y. \& Winsnes, T. S. 1979: Hecla Hock rocks of Oscar II Land and Prins Carls Forland. Svalbard. Nor. Polarinst. Skr. 167, 145-169.

Horsfield, W. T. 1972: Glaucophane schists of Caledonian age from Spitsbergen. Geol. Mag. 109, 29-36.

Lindström, M. 1955: Conodonts from the lowermost Ordovician strata of south-central Sweden. Geol. Fören. Stockh. Förh. $76,517-604$.

Löfgren. A. 1978: Arenigian and Llanvirnian conodonts from Jämtland, northern Sweden. Fossils and Strata 13,129 pp., 16 pls.

Ohta, Y. 1979: Blueschists from Motalafjella, western Spitsbergen. Nor. Polarinst. Skr. 167, 171-217. 
Ohta, Y., Hiroi, Y. \& Hirajima, T. 1984: Additional evidence of pre-Silurian high-pressurc metamorphic rocks in Spitsbergen. Polar Research 1, n.s., 215-218.

Ohta, Y., Hirajima, T. \& Hiroi, Y. 1986: Caledonian highpressure metamorphism in central western Spitsbergen. In Evans, B. W. \& Brown, E. H. (eds.): Blueschists and eclogites. U.S. Geol. Soc. Memoir 164.

Repetski, J. E. \& Ethington, R. L. 1977; Conodonts from
Graptolite facies in the Ouachita Mountains, Arkansas and Oklahoma. Arkansas Geol. Comm. Symp. on Geol. of Ouachita Mts. I, 92-106.

Scrutton, C. T., Horsfield, W. T. \& Harland, W. B. 1976: Silurian fossils from western Spitsbergen. Geol. Mag. 113, 519-523.

Ziegler, W. (ed.) 1981: Catalogue of Conodonts, Volume IV. Schweitzerbart'sche Verlagsbuchhandlung, Stuttgart. 